\title{
Analisis Pengaruh Indeks Bursa Global Dan Regional Terhadap Indeks Harga Saham Gabungan (IHSG) pada Bursa Efek Indonesia
}

$$
\begin{gathered}
\text { Afriyeni } \\
\text { (Dosen pada Akademi "KBP" Padang) }
\end{gathered}
$$

\begin{abstract}
This research is aimed to examine the influence of global and regional indexes for the stock price index in Indonesian Stock Exchange and to determine the influence of global market stock price indices simultaneously or partially represented by three global stock markets to index IDX. As for the third global stock market Hang Seng is representing Hongkong stock exchange, Nasdaq composite representing the United States Stock Market and the Exchange FTSE representing Malaysia. This research is a statistical study with data population composite stock price index (CSPI) each - one index per - end of month from September 2005 to August 2012. Simple sampling method used to collect data during the 84 months from September 2005 to August 2012. Processing of data obtained from the following regression equation: $Y=-1696.585-207$ IXIC $-0.058+4.689$ HSI. From the regression model constant value of - 1,696.585 states if there is no movement of the three independent variables, then the index will be decreased by $1696.585 \%$. IXIC regression coefficient of -0.207 states that every $1 \%$ decrease IXIC index will result in an increase of $0.207 \%$ assuming constant HSI and FTSE. HSI regression coefficient of - 0.058 states that every $1 \%$ decrease in HSI index will result in an increase of $0.058 \%$ assuming HSI and FTSE konstan.Koefisien regression of 4.689 states that every $1 \%$ increase in FTSE index will result in an increase of $4.689 \%$ assuming IXIC and HSI constant.

The results showed that the influence of these three global stock index jointly significant influence but individually only Hang Seng stock index and HSI are affecting the BEI index. Data processing results obtained $R$ Square of 0.934, which means 93.4\% movement in the Indonesia Stock Exchange Composite Index is affected by movements in global and regional indices.
\end{abstract}

\section{Pendahuluan}

Proses globalisasi dari sisi ekonomi adalah suatu perubahan di dalam perekonomian dunia, yang bersifat mendasar atau struktural dan akan berlangsung terus dalam laju yang semakin pesat, mengikuti kemajuan teknologi yang juga prosesnya semakin cepat (Tambunan, 1998). Perkembangan ini telah meningkatkan kadar hubungan saling ketergantungan dan juga mempertajam persaingan antarnegara, tidak hanya dalam 
perdagangan internasional tetapi juga dalam kegiatan investasi, finansial dan produksi. Globalisasi ekonomi ditandai dengan semakin menipisnya batas-batas kegiatan ekonomi atau pasar secara nasional atau regional. Misalnya, dalam pasar global saat ini, setiap investor dapat berinvestasi dimanapun yang dia inginkan dan dianggap menguntungkan bagi investor tersebut.

Dampak dari globalisasi disisi ekonomi, khususnya pada pasar finansial sangatlah besar. Contoh, krisis yang terjadi di Amerika Serikat, yang disebabkan oleh jatuhnya harga surat utang berbasis kredit perumahan Subprime Mortgage di Amerika Serikat pada bulan Agustus tahun 2007, langsung menggoyang pasar finansial hampir di seluruh dunia. Peristiwa tersebut telah mempengaruhi mekanisme investasi dan perdagangan secara global di pasar modal dunia dan telah berdampak terhadap investor di Amerika Utara, Eropa, Australia, dan Asia (Crouhy dan Turnbull, 2008).

Krisis yang terjadi telah menyebabkan beberapa bursa saham global mengalami penurunan yang cukup signifikan, dimana pasar saham dunia mengalami koreksi besar pada 2 periode. Periode pertama dimulai sejak awal Februari 2007 dan berakhir pada pertengahan Maret 2007, sedangkan periode kedua dimulai sejak akhir Juli 2007 dimana menurut Soros terjadi puncaknya pada bulan Agustus 2007.

Bursa Efek Indonesia (BEI) pada hari Rabu, 8 Oktober 2008 melakukan suspend atau pemberhentian sementara perdagangan, yang berakibat anjloknya nilai saham-saham yang listing di BEI sebagai akibat krisis finansial global. Hal ini tidak hanya terjadi di Indonesia saja, hampir seluruh bursa di dunia mengalami penurunan yang besar, contoh: bursa di Amerika Serikat dan Eropa mengalami penurunan antara 3,74\% (DAX Jerman) hingga $5,11 \%$ (Index DowJones). Hal yang serupa juga terjadi di Asia dimana indeks utama seperti Nikkei dan Hang Seng mengalami penurunan masing-masing sebesar 9,34\% dan 4,83\%. Sedangkan di regional Asean, penurunan juga terjadi seperti KLCI $(2,53 \%)$ dan SETI (5,76\%) (sumber :Wealth Management GroupBank Mandiri, 2008).

Selama tahun 2008 hampir semua bursa global mencatat penurunan yang besar sekaligus menorehkan catatan terburuk. Indeks Harga Saham Gabungan (IHSG) sendiri ketika pada bulan Desember 2008 tercatat turun 51,17\% ke level 1.340,89. IHSG di bursa efek Indonesia mencatat penurunan yang terburuk ke empat setelah indeks saham di Shenzen, Shanghai, dan Mumbai (www.detikfinance.com).

Bagi Indonesia sendiri, melemahnya IHSG pada BEI akibat sentimen global krisis keuangan Amerika Serikat sebenarnya memberikan hikmah positif, karena tanpa disadari kinerja IHSG selama ini relatif over-valued. Turunnya IHSG kelevel saat ini lebih mewakili kondisi fundamental yang sebenarnya (priced-in). Meski level IHSG pada saat tersebut dipastikan merupakan level equilibrium baru, tetapi dengan kondisi fundamental yang perform akan menahan aksi spekulasi yang mendorong IHSG terkoreksi lebih dalam (Purna dkk, 2009).

Disaat krisis melanda Amerika Serikat, mengakibatkan turunnya daya beli masyarakat, nilai ekspor Indonesiapun jadi turun. Laba perusahaan-perusahaan yang bisnisnya berkaitan dengan ekspor ke Amerika Serikat pun akan turun, dan otomatis akan menyebabkan laba perusahaan-perusahaan tersebut turun. Dengan turunnya laba perusahaan tersebut mengakibatkan deviden pemegang saham ikut turun dan permintaan terhadap saham tersebut berkurang, yang menyebabkan harga saham jatuh. Dengan banyaknya harga saham yang turun menyebabkan Indeks Harga Saham Gabungan-pun akan turun. Sebagaimana telah dijelaskan diatas bahwa IHSG adalah salah satu variabel ekonomi makro, sehingga IHSG suatu negara yang kuat akan berpengaruh terhadap IHSG dari negara yang lemah. 
Penelitian yang dilakukan oleh Achsani (2001) tentang bagaimana bursa merespon terhadap shock dari bursa lain, apabila terjadi shock di Amerika Serikat, maka bursa-bursa regional tidak akan terlalu meresponnya. Hanya di Singapura, Hong Kong, Jepang, Taiwan dan New Zealand yang akan langsung merespon, dan respon pun tidak cukup besar. Sebaliknya jika shock di Singapura, Australia atau Hong Kong, secara cepat shock tersebut akan ditransmisikan ke hampir semua bursa saham di Asia Pasifik, termasuk Bursa Efek Indonesia. Penelitian serupa juga dilakukan oleh Utama (2008), yang meneliti mengenai pengaruh pasar saham dunia terhadap pasar saham Indonesia yang menyatakan bahwa terdapat hubungan yang saling mempengaruhi antar pasar saham Singapura, Hongkong, dan Jepang terhadap pasar saham Indonesia.

Dalam penelitian ini penulis ingin meneliti pengaruh indeks bursa global dan regional terhadap indeks harga saham gabungan pada bursa efek Indonesia, yang mana untuk bursa global diwakili oleh $N A S D A Q$ Composite, dan untuk regional diwakili oleh indeks Hang Seng dan KLSE.

\section{Tinjauan Literatur}

\section{Investasi}

Investasi adalah komitmen atas sejumlah dana atau sumber daya lainnya yang dilakukan pada saat ini, dengan tujuan memperoleh sejumlah keuntungan di masa yang akan datang (Tandelilin, 2001). Jogiyanto (2002) mengartikan investasi sebagai penundaan konsumsi sekarang untuk digunakan di dalam produksi yang efisien selama periode waktu tertentu. Istilah investasi bisa berkaitan dengan berbagai macam aktivitas. Menginvestasikan sejumlah dana pada asset rill (tanah, emas, mesin, dan bangunan) maupun asset financial (deposito, saham, dan obligasi) merupakan aktivitas investasi yang umumnya dilakukan investor.

\section{Pasar Modal}

Pasar modal adalah pertemuan antara pihak yang memiliki kelebihan dana dengan pihak yang membutuhkan dana dengan cara memperjualbelikan sekuritas (Tandelilin, 2001). Jones (2002) memahami pasar modal sebagai tempat perusahaan yang akan melakukan perkembangan usaha dan membutuhkan dana untuk mengembangkan usahanya dan sejalan dengan itu pemerintah menjamin sejumlah dana yang besar untuk menyediakan barang dan jasa untuk memenuhi permintaan orang-orang.

Undang-undang Pasar Modal No. 8 Tahun 1995 memberikan pengertian yang lebih spesifik tentang pasar modal, yaitu: "Kegiatan yang bersangkutan dengan penawaran umum dan perdagangan efek, perusahaan publik yang berkaitan dengan efek yang diterbitkannya serta lembaga yang berkaitan dengan efek". Efek merupakan istilah baku yang digunakan undang-undang Pasar modal No. 8 tahun 1995 untuk menyatakan surat berharga atau sekuritas. Pasar modal merupakan sarana perusahaan untuk meningkatkan kebutuhan dana jangka panjang dengan menjual sahamnya atau mengeluarkan obligasi, dimana saham merupakan bukti pemilikan sebagian dari perusahaan.

Definisi pasar modal menurut Elton dan Grubber (1995:14) yang dikutip dari Mansur (2005) adalah: "Capital market securities include instruments with maturities greater than one year and those with no designated maturity at all". Dengan semakin berkembangnya sarana komunikasi dan teknologi informasi, disertai pula dengan adanya deregulasi keuangan telah menghilangkan batasan antara pasar keuangan domestik dengan pasar keuangan asing. 


\section{Indeks Harga Saham Gabungan}

Indeks harga saham merupakan indikator utama yang menggambarkan pergerakan harga saham. Di pasar modal sebuah indeks diharapkan memiliki fungsi (Gouzdili, 2006), yaitu sebagai indikator trend pasar, sebagai indikator tingkat keuntungan, sebagai tolak ukur (banchmark) kinerja suatu portofolio, memfasilitasi pembentukan portofolio dengan strategi pasif, memfasilitasi berkembangnya produk derivative.

Indeks Harga Saham Gabungan merupakan ringkasan dari pengaruh simultan dan kompleks dari berbagai macam variabel yang berpengaruh, terutama tentang kejadiankejadian ekonomi. Bahkan saat ini Indeks Harga Saham Gabungan juga menampung kejadian-kejadian sosial, politik dan keamanan. Dengan demikian, Indeks Harga Saham Gabungan dapat dijadikan barometer kesehatan ekonomi suatu negara dan sebagai dasar melakukan analisis statistik atas kondisi pasar terakhir (Halim,2005).

\section{Gambaran Bursa Global}

Kerjasama antar bursa efek atau aliansi antara AMEX (American Stock Exchange) dan NASDAQ (Nasional Association of Securuties Dealers Automated Qoutation) yang keduanya berlokasi di Amerika Serikat, Nasdaq (Amerika Serikat) dan LSE (London Stock Exchange) di Inggris, Nasdaq (Amerika Serikat) dan SES (Stock Exchange of Singapore), tidak lain untuk menarik investor (Samsul, 2006). Investor di Singapura yang ingin membeli saham yang tercatat di Nasdaq tidak harus datang ke Amerika Serikat, tetapi cukup menaruh order beli di anggota bursa SES. Demikian juga, investor di London cukup menaruh order beli atau order jual pada anggota bursa LSE apabila ingin melakukan transaksi saham asing yang tercatat di Nasdaq. Pada akhir tahun 1995, 670 emiten asing mencatatkan sahamnya di Amerika Serikat, dimana tiga di antaranya berasal dari Indonesia, yaitu PT. Tambang Timah, PT. Telkom, dan PT. Indosat melalui teknik ADR's (American Depository Receipts).

Pesatnya perkembangan perdagangan saham tanpa penyerahan fisik saham (scripless trading) berdampak luas. Perdagangan dapat menjangkau jarak jauh karena penyerahan saham tidak dilakukan secara fisik, tetapi hanya dilakukan melalui proses balik nama dengan cara pemindahbukuan (over booking atau booking entries) di central custodian (Pusat Penyimpanan Efek di suatu negara).

\section{Penelitian Terdahulu}

Utama (2008) meneliti tentang Pengaruh Pasar Saham Dunia Terhadap Pasar Saham Indonesia dengan menggunakan data harian indeks harga saham gabungan dari pasar saham Amerika Serikat, Singapura, Jepang, Hongkong dan Indonesia yang mencakup periode Juli 1997 sampai Juli 2008. Penelitian ini menghasilkan kesimpulan bahwa ada hubungan antara pasar saham dunia dengan pasar saham Indonesia. Pasar saham dunia terutama pasar saham Amerika Serikat lebih mempengaruhi pasar saham Indonesia dan hanya pada saat krisis tahun 1997 saja pasar saham Indonesia mempengaruhi pasar saham Amerika Serikat. Sebagian besar hubungan kausalitas yang ada, terutama pasar saham Asia adalah hubungan kausalitas saling mempengaruhi dengan pasar saham Indonesia. Terdapat interdependensi pasar saham Indonesia dengan pasar saham Asia.

Mansur (2005) menguji Pengaruh Indeks Bursa Global Terhadap Indeks Harga Saham Gabungan (IHSG) pada Bursa Efek Jakarta (BEJ) Periode Tahun 2000 - 2002, menyimpulkan bahwa hasil dari pengujian analisis jalur model menunjukan bahwa indeks harga saham gabungan bursa global secara bersama-sama memberikan pengaruh yang signifikan terhadap Indeks Harga Saham Gabungan di BEJ. Sedangkan pengujian secara 
individual dari ketujuh indeks bursa global tersebut bursa saham Hong Kong, New York dan London tidak memiliki pengaruh yang signifikan terhadap Indeks Harga Saham Gabungan di Bursa Efek Jakarta dalam periode waktu penelitian yaitu tahun 2000 sampai dengan tahun 2002.

Pengaruh yang cukup signifikan terhadap Indeks Harga Saham Gabungan Jakarta ditunjukkan oleh indeks bursa Korea, indeks bursa Tokyo, indeks bursa Taiwan dan indeks bursa Australia. Dari analisis yang dilakukan ke empat bursa saham memberikan pengaruh yang signifikan sebesar 75,944\%. Dari keempat indeks bursa saham tersebut bursa saham Korea (KOSPI) yang paling dominan mempengaruhi Indeks Bursa Saham Gabungan di Bursa Efek Jakarta dengan nilai pengaruh yang signifikan sebesar $61,12 \%$, kemudian indeks bursa saham Tokyo (Nikkei 225) sebesar 44,61\%, lalu indeks bursa saham Taiwan (TAIEX) sebesar $-29,296 \%$ dan indeks bursa saham Australia hasilnya paling kecil tetapi secara statistik turut berpengaruh secara signifikan sebesar 0,06\%. Dibandingkan antara ke tujuh pasar modal global yang diteliti, pasar modal regional Asia dan Australia akan lebih mempengaruhi pasar modal Indonesia dibandingkan dengan pengaruh yang diberikan dari pasar modal dari kawasan Eropa dan Amerika.

\section{Kerangka Pemikiran}

Kerangka penelitian untuk menguji pengaruh Indeks Harga Saham Gabungan dari Nasdaq Composite (IXIC), Indeks Hang Seng ( HSI ), dan Indeks Kuala Lumpur (KLSE), terhadap Indeks Harga Saham Gabungan (IHSG) di Indonesia seperti pada gambar 1.

Gambar 1. Kerangka Konseptual

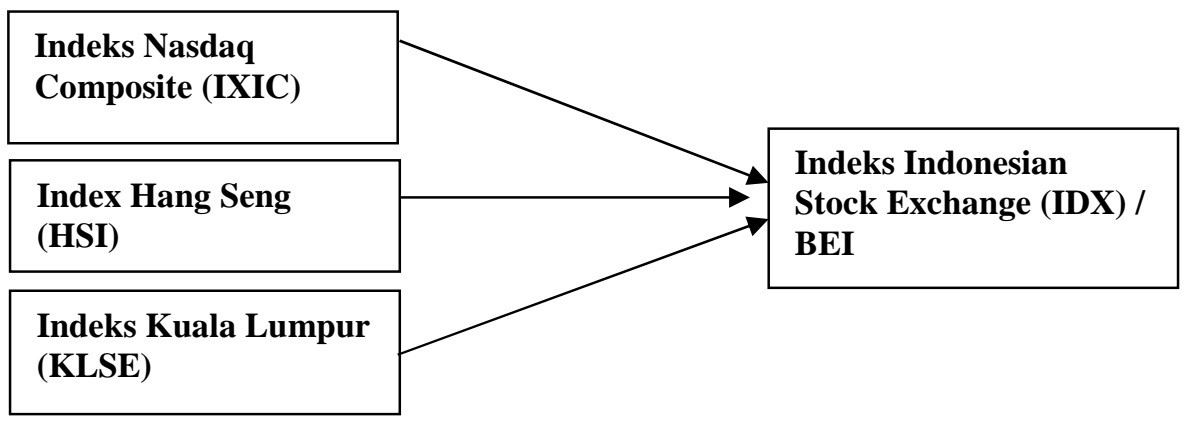

Berdasarkan gambar 1 diketahui bahwa Indeks Nasdaq Composite, Indeks Hang Seng dan Indeks Kuala Lumpur secara parsial dan serempak akan mempengaruhi kondisi indeks harga saham gabungan (IHSG) pada bursa efek Indonesia (BEI).

\section{Hipotesis}

Ha1 : diduga bahwa Indeks Nasdaq Composite(IXIC) berpengaruh terhadap Indeks Harga Saham Gabungan BEI (IDX)

Ha2 : diduga bahwa Indeks Hang Seng berpengaruh terhadap Indeks Harga Saham Gabungan BEI (IDX) 
Ha3 : diduga bahwa Indeks KLSE berpengaruh terhadap Indeks Harga Saham Gabungan BEI (IDX).

\section{Definisi Operasional Variabel}

\section{Variabel Dependen}

Variabel terikat atau "dependent variable" yaitu merupakan variabel yang dipengaruhi oleh variabel bebas. Adapun variabel terikat dalam penelitian ini adalah: Indeks Harga Saham Gabungan ( IHSG ) Bursa Efek Indonesia (Y).

\section{Variabel Bebas}

Variabel bebas atau (Independent Variable) merupakan variabel yang dapat mempengaruhi variabel terikat. Adapun yang merupakan variabel-variabel bebas (independent variable) $(\mathrm{X})$ adalah:

1. $\left(\mathrm{X}_{1}\right)$ Nasdaq Composite (Ixic)

Nasdaq Composite merupakan pasar saham setelah Dow Jones di Amerika Serikat. Sementara posisi Amerika Serikat sebagai lokomotif perekonomian dunia dapat menggambarkan ekonomi global dan tentunya pasar sahamnya mencerminkan keadaan ekonomi Negara tersebut khususnya dan dunia barat umumnya, dan peneliti menganggap Nasdaq Composite dapat mewakili pasar saham Amerika Serikat setelah indeks Dow Jones.

2. $\left(\mathrm{X}_{2}\right)$ Index Hang Seng (Hsi)

Indeks Hang Seng Index adalah sebuah indeks pasar saham berdasarkan kapitalisasi di Bursa Saham Hong Kong. Indeks ini digunakan untuk mendata dan memonitor perubahan harian dari perusahaan-perusahaan terbesar di pasar saham Hong Kong dan sebagai indikator utama dari performa pasar di Hong Kong.

3. $\left(\mathrm{X}_{3}\right)$ Indeks Kuala Lumpur (Klse)

Kuala Lumpur Stock Excange (KLSE) adalah bursa saham Malaysia,bursa efek Negara ini mewakili indeks pasar saham yang paling dekat dengan Indonesia, karena negara ini berbatasan langsung dengan Indonesia, yang berkemungkinan akan saling mempengaruhi dalam sosial, budaya dan ekonomi.

\section{Populasi dan Sampel Penelitian}


Populasi dalam penelitian ini meliputi indeks-indeks harga saham global, termasuk Indeks Harga Saham Gabungan (IHSG) pada Bursa Efek Indonesia pada periode September 2005 hingga Agustus 2012. Sedangkan sampel pada penelitian ini adalah data bulanan selama 7 tahun mulai dari periode bulan September 2005 sampai bulan Agustus 2012 dari indeks harga saham gabungan (IHSG) pada variabel - variabel tersebut.

Data yang diperoleh dalam penelitian ini akan dianalisis dengan menggunakan metode statistik untuk menguji hipotesis dengan menggunakan metode analisis regresi berganda dengan menggunakan program SPSS (Statistical Program for Social Science) versi 16.0 .

\section{Model}

Untuk menguji hubungan variable dependen dengan variable independen digunakan model regresi berganda berikut:

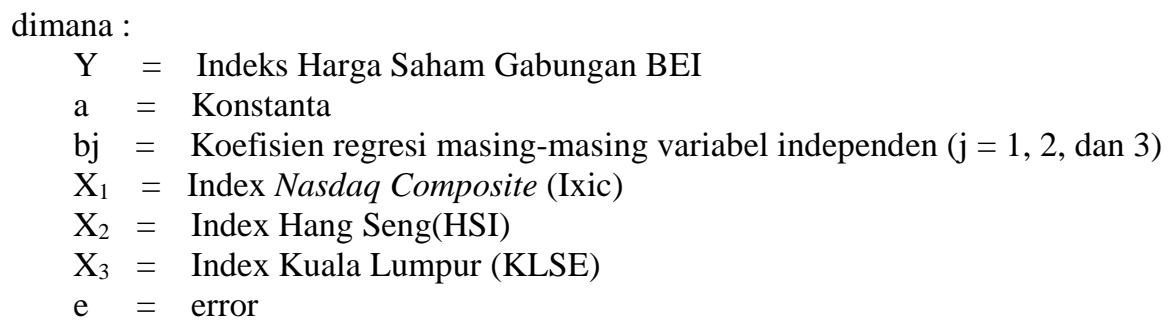

Sebelum melakukan uji statistik dan pengambilan keputusan terlebih dahulu dilakukan pendeskripsian variabel-variabel penelitian. Kemudian variabel-variabel yang akan diuji harus memenuhi asumsi-asumsi dasar yang disebut dengan uji asumsi klasik untuk memperoleh model dengan ketelitian yang tinggi agar hasil analisis nantinya dapat diinterprestasikan secara akurat.

\section{PEMBAHASAN}

\section{Uji Statistik Deskriptif}

Uji deskriptif bertujuan untuk memberikan gambaran mengenai nilai Mean, Sum, Standar Deviasi, Variance, Range, Minimum dan Maximum (Nugroho, 2005:15 dalam Mulditania, 2009).

Hasil perhitungan statistik deskriptif dalam penelitian ini dapat dilihat pada tabel 1 yang menunjukkan bahwa nilai rata-rata variabel dependen yaitu Indeks Harga Saham Gabungan BEI(IDX) adalah sebesar 2559,16, dan standar deviasi sebesar 975,96. Sedangkan untuk variabel independen, seperti Nasdaq Composite-IXIC $\left(\mathrm{X}_{1}\right)$ mempunyai rata-rata sebesar 2383,81 dan standar deviasi sebesar 384,51. Untuk variabel Index Hang Seng-HSI 
$\left(\mathrm{X}_{2}\right)$ mempunyai rata-rata sebesar 20174,54 dan standar deviasi sebesar 3590,65. Variabel Indeks Kuala Lumpur-KLSE $\left(\mathrm{X}_{3}\right)$ mempunyai rata-rata sebesar 1260,89 dan standar deviasi sebesar 241,53.

\section{Korelasi Antar Variabel}

Untuk analisis korelasi antar variabel diperoleh hasil sebagai berikut (tabel 2) koefisien korelasi antara IXIC dengan IDX 0,73 berarti keeratan korelasi antara IXIC dengan IDX sangat kuat. Koefisien korelasi antara HSI dengan IDX 0,51berarti keeratan korelasi antaraHSI dengan IDX kuat. Koefisien korelasi antara KLSE dengan IDX 0,95berarti keeratan korelasi antaraKLSE dengan IDX sangat kuat sekali.

Tabel 1. Hasil perhitungan deskriptif statistik

Descriptive Statistics

\begin{tabular}{|c|c|c|c|c|c|}
\hline & $\mathrm{N}$ & Minimum & Maximum & Mean & Std. Deviation \\
\hline IHSG BEI - IDX (Y) & 84 & 1066.22 & 4262.56 & 2559.1624 & 975.96112 \\
\hline NASDAQ - IXIC $\left(\mathrm{X}_{1}\right)$ & 84 & 1377.84 & 3116.23 & 2383.8187 & 384.51076 \\
\hline Hang Seng - HSi $\left(\mathrm{X}_{2}\right)$ & 84 & 12811.57 & 31352.58 & 20174.5485 & 3590.65971 \\
\hline Kuala Lumpur-KLSE $\left(\mathrm{X}_{3}\right)$ & 84 & 863.61 & 1646.11 & 1260.8968 & 241.53415 \\
\hline Valid N (listwise) & 84 & & & & \\
\hline
\end{tabular}

Tabel 2. Korelasi antar Variabel Penelitian

\begin{tabular}{|ll|r|r|r|r|}
\hline & & IDX & \multicolumn{1}{|c|}{ IXIC } & \multicolumn{1}{c|}{ HSI } & \multicolumn{1}{c|}{ KLSE } \\
\hline Pearson & IDX & 1.000 & .736 & .519 & .951 \\
& & .736 & 1.000 & .601 & .815 \\
& IXIC & .519 & .601 & 1.000 & .673 \\
& HSI & .951 & .815 & .673 & 1.000 \\
\hline KLSE & KLSE (1-tailed) & IDX & .000 & .000 & .000 \\
& & .000 &. & .000 & .000 \\
& IXIC & .000 & .000 &. & .000 \\
& HSI & .000 & .000 & .000 &. \\
& KLSE & .000 & .000 & \\
\end{tabular}




\begin{tabular}{|ll|l|l|l|l|}
\hline $\mathrm{N}$ & IDX & 84 & 84 & 84 & 84 \\
& & 84 & 84 & 84 & 84 \\
IXIC & 84 & 84 & 84 & 84 \\
HSI & 84 & 84 & 84 & 84 \\
\hline
\end{tabular}

Sumber : data diolah

\section{Uji Normalitas}

Uji normalitas bertujuan untuk menguji apakah model regresi variabel terikat dan variabel bebas keduanya mempunyai distribusi normal atau tidak (Ghozali, 2002 mengutip dalam Rahmayuni, 2008). Data yang baik dan layak digunakan dalam penelitian adalah data yang memiliki distribusi normal. Uji normalitas dalam pengujian ini menggunakan onesample Kolmogorov Smirnov dengan tingkat signifikansi 0,05. Jika probabilitas Asymp. Sig. (2-tailed) residual model regresi diatas 0,05, maka dapat dikatakan bahwa asumsi normalitas terpenuhi.

Tabel 3. Hasil Uji Normalitas

One-Sample Kolmogorov-Smirnov Test

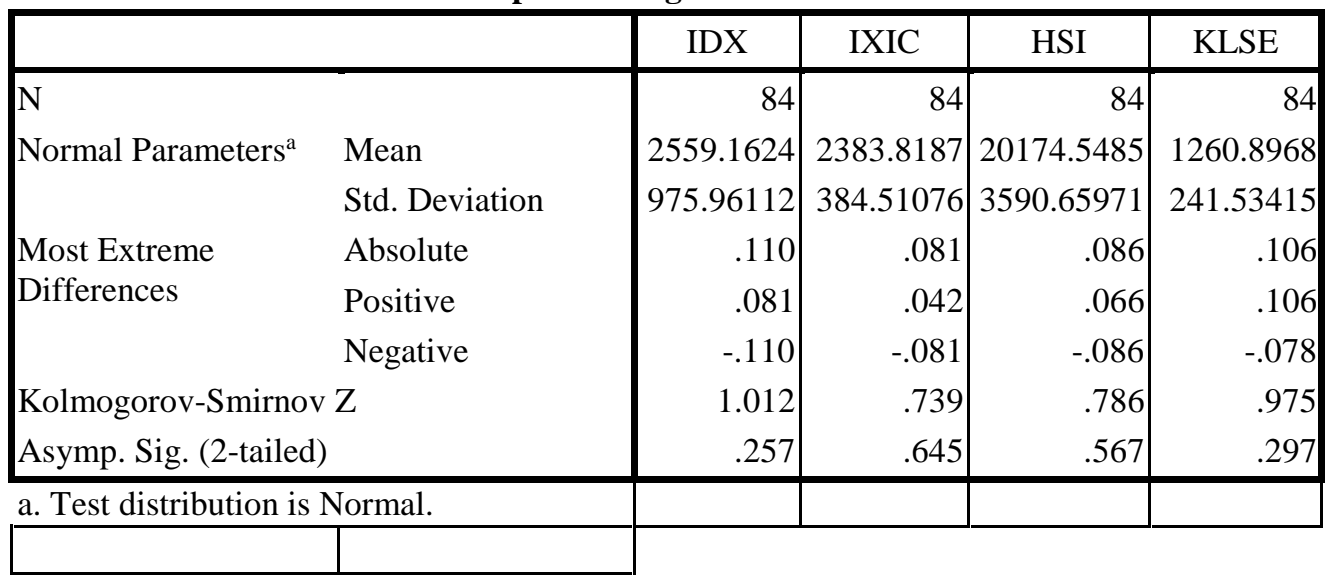

Asymp signifikan untuk variabel $\mathrm{Y}, \mathrm{X} 1, \mathrm{X} 2$, dan $\mathrm{X} 3$ secara berturut-turut adalah 0,257 untuk $\mathrm{Y}, 0,645$ untuk $\mathrm{X}_{1}, 0,567$ untuk $\mathrm{X}_{2}$, dan 0,297 untuk $\mathrm{X}_{3}$. Dari hasil tersebut nampak bahwa semua variabel mempunyai tingkat signifikansi atau nilai probabilitas di atas 0,05 , maka bisa dikatakan penelitian memiliki distribusi normal.

\section{Uji Asumsi Klasik}

\section{Uji Multikolinearitas}

Uji multikolinearitas dilakukan untuk mengetahui ada tidaknya variabel independen yang memiliki kemiripan dengan variabel independen lain dalam suatu model. Kemiripan antarvariabel independen dalam suatu model akan menyebabkan terjadinya korelasi yang sangat kuat antara satu variabel independen dengan variabel independen yang lain. 
Tabel 4. Hasil Uji Multikolinearitas

Coefficients $^{\mathbf{a}}$

\begin{tabular}{|c|c|c|c|c|c|c|c|c|}
\hline & & \multicolumn{2}{|c|}{$\begin{array}{c}\text { Unstandardized } \\
\text { Coefficients }\end{array}$} & \multirow{2}{*}{\begin{tabular}{|c|}
$\begin{array}{c}\text { Standardized } \\
\text { Coefficients }\end{array}$ \\
Beta
\end{tabular}} & \multirow[b]{2}{*}{$\mathrm{T}$} & \multirow[b]{2}{*}{ Sig. } & \multicolumn{2}{|c|}{$\begin{array}{l}\text { Collinearity } \\
\text { Statistics }\end{array}$} \\
\hline \multicolumn{2}{|c|}{ Model } & B & Std. Error & & & & Tolerance & VIF \\
\hline 1 & (Constant) & -1696.585 & 189.590 & & -8.949 & .000 & & \\
\hline & IXIC & -.207 & .127 & -.081 & -1.628 & .107 & .331 & 3.019 \\
\hline & HSl & -.058 & .011 & -.212 & -5.409 & .000 & .539 & 1.855 \\
\hline & KLSE & 4.689 & .218 & 1.160 & 21.472 & .000 & .284 & 3.522 \\
\hline
\end{tabular}

a. Dependent Variable:

IDX

Berdasarkan pengujian melalui Variance Inflation Factor (VIF) pada hasil output SPSS di atas, masing-masing variabel independen memiliki VIF tidak lebih dari 10 dan nilai Tolerance tidak kurang dari 0,1. Besaran VIF variabel independen Nasdaq (IXIC) memiliki nilai sebesar 3,019, Hang Seng (HSI) dengan nilai sebesar 1,855, dan Kuala Lumpur (KLSE) sebesar 3,522. Sedangkan nilai tolerance masing-masing variabel yaitu 0,331, 0,539, 0,284. Maka dapat dinyatakan model regresi linear berganda terbebas dari asumsi klasik (multikolinearitas) dan dapat digunakan dalam penelitian.

\section{Uji Autokorelasi}

Tabel 5. Hasil Uji Autokorelasi

Model Summary ${ }^{b}$

\begin{tabular}{|l|r|r|r|r|r|}
\hline Model & \multicolumn{1}{|c|}{$\mathrm{R}$} & R Square & $\begin{array}{c}\text { Adjusted R } \\
\text { Square }\end{array}$ & $\begin{array}{c}\text { Std. Error of the } \\
\text { Estimate }\end{array}$ & Durbin-Watson \\
\hline 1 & $.966^{\mathrm{a}}$ & .934 & .931 & 256.01874 & .484 \\
\hline
\end{tabular}

a. Predictors: (Constant), KLSE, HSI, IXIC

b. Dependent Variable: IDX

Dari hasil pengujian di atas terlihat nilai Durbin Watson hitung sebesar 0,484 yang berada pada interval -2 s.d +2 berarti bahwa tidak ada autokorelasi. Maka dapat disimpulkan model regresi linear berganda terbebas dari asumsi klasik autokorelasi.

\section{Koefisien Regresi}

Uji Parsial dengan $\mathrm{t}$ - test

Tabel 6. Hasil Uji Parsial

Coefficients $^{\mathrm{a}}$

\begin{tabular}{|c|c|c|c|c|c|}
\hline Model & $\begin{array}{l}\text { Unstandardized } \\
\text { Coefficients }\end{array}$ & $\begin{array}{c}\text { Standardize } \\
\mathrm{d} \\
\text { Coefficients }\end{array}$ & $\mathrm{T}$ & Sig. & $\begin{array}{c}\text { Collinearity } \\
\text { Statistics }\end{array}$ \\
\hline
\end{tabular}




\begin{tabular}{|rr|r|r|r|r|r|r|r|}
\hline & & & & & & $\begin{array}{r}\text { Toleranc } \\
\mathrm{e}\end{array}$ & $\mathrm{VIF}$ \\
\hline 1 & (Constant) & -1696.585 & 189.590 & & -8.949 & .000 & & \\
& IXIC $\left(\mathrm{X}_{1}\right)$ & -.207 & .127 & -.081 & -1.628 & .107 & .331 & 3.019 \\
& HSI $\left(\mathrm{X}_{2}\right)$ & -.058 & .011 & -.212 & -5.409 & .000 & .539 & 1.855 \\
& KLSE( $\left.\mathrm{X}_{3}\right)$ & 4.689 & .218 & 1.160 & 21.472 & .000 & .284 & 3.522 \\
\hline
\end{tabular}

a. Dependent Variable: IDX

Hipotesis pertama menguji apakah Indeks Nasdaq Composite(IXIC) berpengaruh terhadap Indeks Harga Saham Gabungan BEI (IDX). Tabel 6 menunjukkan bahwa variabel Indeks Nasdaq Composite (IXIC) memiliki nilai p-value 0,107>0,05 artinya tidak signifikan, sedangkan t-hitung $-1,628<$ dari t-tabel 2,02 artinya tidak signifikan. Dengan demikian, dapat disimpulkan bahwa Indeks Nasdaq Composite(IXIC)tidak berpengaruh terhadap Indeks Harga Saham Gabungan BEI.

Hipotesis kedua menguji apakah Indeks Hang Seng berpengaruh terhadap Indeks Harga Saham Gabungan. Tabel 6 menunjukkan bahwa variabel indeks Hang Seng memiliki nilai p-value $0,000<0,05$ artinya signifikan, sedangkan t-hitung $-5,409>\mathrm{t}$-tabel 2,02 artinya signifikan. Dengan demikian, dapat disimpulkan bahwa Indeks Hang Seng secara parsial berpengaruh negatif signifikan terhadap Indeks Harga Saham Gabungan BEI. Negatif signifikan ini berarti jika Indeks Hangseng mengalami penurunan maka akan berimbas positif terhadap IHSG yang akan mengalami kenaikan, begitu juga sebaliknya.

Hipotesis ketiga menguji apakah Indeks KLSE berpengaruh terhadap Indeks Harga Saham Gabungan. Tabel 6 menunjukkan bahwa variabel indeks KLSE memiliki nilai p-value $0,000<0,05$ artinya signifikan, sedangkan t-hitung 21,472>t-tabel 2,02 artinya signifikan.

Dengan demikian dapat disimpulkan bahwa Indeks KLSE secara parsial berpengaruh positif signifikan terhadap Indeks Harga Saham Gabungan BEI. Dengan artian bahwa jika indeks KLSE mengalami kenaikan, maka IHSG pun mengalami kenaikan, dan sebaliknya.

Tabel 7. Tabel Ringkasan Uji Parsial dengan $\mathrm{t}$ - test

\begin{tabular}{|l|l|l|l|}
\hline \multicolumn{1}{|c|}{ Hipotesis } & p-value & $\begin{array}{c}\text { t-Hitung : t- } \\
\text { Tabel }\end{array}$ & \multicolumn{1}{c|}{ Kesimpulan } \\
\hline $\begin{array}{l}\text { Apakah Indeks Nasdaq } \\
\text { Composite berpengaruh } \\
\text { terhadap IHSG BEI }\end{array}$ & $0,107>0,05$ & $-1,628<2,02$ & $\begin{array}{l}\text { Indeks Nasdaq Composite tidak } \\
\text { berpengaruh terhadap Indeks } \\
\text { Harga Saham Gabungan BEI. }\end{array}$ \\
\hline $\begin{array}{l}\text { Apakah Indeks Hang Seng } \\
\text { berpengaru terhadap } \\
\text { Indeks Harga Saham } \\
\text { Gabungan }\end{array}$ & $0,000<0,05$ & $-5,409>2,02$ & $\begin{array}{l}\text { Indeks Hang Seng secara parsial } \\
\text { berpengaruh negatif signifikan } \\
\text { terhadap Indeks Harga Saham } \\
\text { Gabungan BEI. Negatif } \\
\text { signifikan ini berarti jika Indeks } \\
\text { Hangseng mengalami penurunan } \\
\text { maka akan berimbas positif } \\
\text { terhadap IHSG yang akan } \\
\text { mengalami kenaikan, begitu juga } \\
\text { sebaliknya. }\end{array}$ \\
\hline
\end{tabular}




\begin{tabular}{|l|l|l|l|}
\hline $\begin{array}{l}\text { Apakah Indeks } \\
\text { berpengaruh }\end{array}$ & $\begin{array}{l}\text { KLSE } \\
\text { Indeks Harga }\end{array}$ & Saham \\
Gabungan & $0,000<0,05$ & $21,472>2,02$ & $\begin{array}{l}\text { Indeks KLSE secara parsial } \\
\text { berpengaruh positif signifikan } \\
\text { terhadap Indeks Harga Saham } \\
\text { Gabungan BEI. Dengan artian } \\
\text { bahwa jika indeks KLSE } \\
\text { mengalami kenaikan, maka }\end{array}$ \\
& & $\begin{array}{l}\text { IHSG pun mengalami kenaikan, } \\
\text { dan sebaliknya. }\end{array}$ \\
\hline
\end{tabular}

p-Value: Sig. Variable Independent < Level of Significant

t-hitung $>$ t-table $=$ sig

$(+/-)=$ arah signifikan (Positif/negatif)

\section{Regresi Berganda Variabel IXIC, HSI, dan KLSE terhadap IHSG}

Angka R Square dikatakan baik jika di atas 0,5 karena nilai $R S q u a r e$ berkisar antara 0 sampai 1. Tabel 5 melihatkan bahwa angka $R$ Square-nya sebesar 0,934. Hal ini berarti 93,4 $\%$ dari naik turunnya IHSG dapat dijelaskan oleh IXIC, HSI, dan KLSE. Sementara sisanya sebesar 6,6\% merupakan faktor - faktor lain yang tidak dimasukkan dalam model ini seperti keadaan perekonomian global, hubungan perdagangan antar negara, situasi sosial, politik, dan keamanan serta isu - isu yang memberikan sentimen tertentu kepada perdagangan saham di Bursa Efek Indonesia.

Nilai koefisien determinasi yang sudah disesuaikan (Adjusted $R$ Square) sebesar 0,931. Artinya 93,1\% variabel dependen return market $(\mathrm{Rm})$ IHSG dijelaskan oleh variabel independen IXIC, HSI, dan KLSE, dan sisanya dijelaskan oleh variabel lain di luar variabel yang digunakan. Sehingga dapat disimpulkan bahwa model regresi linear berganda layak digunakan, karena sebagian besar variabel dependen dijelaskan oleh variabel - variabel independen yang digunakan dalam model.

Uji simultan dengan $F$-Test bertujuan untuk mengetahui pengaruh bersama-sama variabel independen terhadap variabel dependen. Hasil F-Test menunjukkan variabel independen secara bersama-sama berpengaruh terhadap variabel dependen atau signifikan jika $p$-value (pada kolom Sig.) < dari level of significant yang ditentukan, atau F hitung > F tabel. Sebaliknya, jika $\mathrm{F}$ hitung $<\mathrm{F}$ tabel, berarti pengaruh variabel independen terhadap variabel dependen tidak signifikan.

Tabel 8 Hasil Uji F-test (ANOVA)

ANOVA $^{b}$

\begin{tabular}{|rl|r|r|r|r|r|}
\hline \multicolumn{1}{|l|}{ Model } & & Sum of Squares & df & Mean Square & \multicolumn{1}{c|}{ F } & \multicolumn{1}{c|}{ Sig. } \\
\hline 1 & Regression & 73813861.293 & 3 & 24604620.431 & 375.382 & $.000^{\mathrm{a}}$ \\
& Residual & 5243647.809 & 80 & 65545.598 & & \\
& Total & 79057509.102 & 83 & & & \\
\hline
\end{tabular}

a. Predictors: (Constant), KLSE, HSI, IXIC

b. Dependent Variable: IDX 
Dari hasil uji F (Uji ANOVA) pada tabel 8, didapat tingkat signifikansi 0,000 ( $p$ value $<0,05$ ), yang artinya signifikan. Sedangkan, untuk F Hitung 375,382> F tabel 2,85, artinya signifikan ( $\mathrm{df} 1=4-1=3$ dan $\mathrm{df} 2=84-4=80$ ). Signifikan di sini berarti $\mathrm{H}_{\mathrm{i}}$ (hipotesis alternatif) diterima dan Ho (hipotesis nol) ditolak. Artinya, IXIC, HSI, dan KLSE secara bersama-sama berpengaruh terhadapIHSG dan model regresi bisa dipakai untuk memprediksi Indeks Harga Saham Gabungan pada BEI.

Oleh karena itu, dari pengolahan data tersebut diperoleh persamaan regresi sebagai berikut:

$$
\text { IHSG }=-1696.585-0,207 \text { IXIC }-0,058 \text { HSI }+4,689 \text { KLSE }
$$

Dari model regresi di atas, nilai konstanta sebesar -1.696,585, hal ini berarti jika tidak ada pergerakan dari ketiga variabel independen, maka IHSG akan mengalami penurunan sebesar $1.696,585 \%$.

Koefisien regresi IXIC sebesar -0,207 menyatakan bahwa setiap penurunan 1 basis point IXIC akan mengakibatkan terjadinya peningkatan IHSG sebesar 0,207 \% dengan asumsi HSI dan KLSE konstan. Koefisien regresi HSI sebesar - 0,058 menyatakan bahwa setiap penurunan $1 \%$ HSI akan mengakibatkan terjadinya peningkatan IHSG sebesar 0,058 $\%$ dengan asumsi IXIC dan KLSE konstan.Koefisien regresi KLSE sebesar 4,689 menyatakan bahwa setiap peningkatan 1\% KLSE akan mengakibatkan terjadinya peningkatan IHSG sebesar 4,689 \% dengan asumsi IXIC dan HSI konstan.

\section{Penutup}

\section{Kesimpulan}

1. Pengujian Asumsi Klasik

a. Berdasarkan pengujian multikolinearitas yang dilakukan, tidak ada ditemukan adanya korelasi antar variabel independen pada model yang digunakan dimana masingmasing variabel independen memiliki VIF tidak lebih dari 10 dan nilai Tolerance tidak kurang dari 0,1 .

b. Berdasarkan uji autokorelasi yang dilakukan, tidak ditemukan adanya masalah autokorelasi, dimana nilai Durbin Watson hitung sebesar 0.484 yang berada pada interval $-2 \mathrm{~s} . \mathrm{d}+2$.

2. Berdasarkan Uji Statistik

a. Dari uji hipotesis secara partial (uji t), diperoleh hasil bahwa Indeks Nasdaq Composite secara parsial tidak berpengaruh signifikan terhadap Indeks Harga Saham Gabungan BEI. Sedangkan Indeks Hang Seng memiliki pengaruh negatif signifikan terhadap Indeks Harga Saham Gabungan pada BEI, sementara Indeks KLSE berpengaruh positif signifikan terhadap Indeks Harga Saham Gabungan pada BEI.

b. Dari hasil regresi berganda diperoleh angka $\mathrm{R}$ square sebesar 0,934. Hal ini berarti 93,4\% dari variasi Indeks Harga Saham Gabungan di Bursa Efek Indonesia bisa dijelaskan oleh variabel Nasdaq Composite, Indeks Hang Seng, dan Indeks KLSE. 
Sementara sisanya $(100 \%-93,4 \%=6,6 \%)$ dijelaskan oleh sebab-sebab yang lain. Sedangkan nilai koefisien determinasi yang sudah disesuaikan (Adjusted R Square) sebesar 0,931. Artinya 93,1\% variabel dependen Indeks Harga Saham Gabungan Bursa Efek Indonesia dijelaskan oleh variabel Independent Nasdaq Composite, Indeks Hang Seng, dan indeks KLSE, dan sisanya $(100 \%-93,1 \%=6,9 \%)$ dijelaskan oleh variabel lain di luar variabel yang digunakan.

c. Dari hasil uji F (Uji Anova), didapat tingkat signifikansi 0,000 ( $p$ value $<0,05$ ), yang artinya signifikan. Sedangkan, untuk F Hitung 375,382> F tabel 2,85, artinya signifikan (df1 = 4-1 = 3 dan df $2=84-4=80$ ). Artinya, IXIC, HSI, dan KLSE secara bersama-sama berpengaruh terhadapIHSG dan model regresi bisa dipakai untuk memprediksi IHSG.

Dari hasil penelitian dapat diambil sebuah kesimpulan yang menyatakan bahwa keterkaitan Indonesia dengan dunia asing sangat erat dan saling mempengaruhi dalam perekonomian khususnya di bursa saham yang tergambar dari Indeks Harga Saham Gabungan masing - masing bursa saham negara tersebut.

\section{Keterbatasan}

Pada penelitian ini hanya menggunakan tiga variabel, yaitu indeks Nasdaq, indeks Hang Seng dan indeks KLSE. Untuk penelitian selanjutnya bisa ditambah dengan indeksindeks lainnya seperti: indeks FTSE, indeks NIKKEI, indeks Straits Times dll.

\section{Saran Penelitian:}

1. Bagi Investor sebaiknya perlu mempertimbangkan keadaan naik turunnya pasar saham lain sebelum memutuskan untuk berinvestasi pada Bursa Efek Indonesia, karena berdasarkan hasil penelitian ini, IHSG BEI dipengaruhi oleh indeks Hang Seng dan KLSE.

2. Bagi Pemerintah dapat menjadikan IHSG sebagai acuan dalam menginterpretasikan keadaan ekonomi.

3. Bagi akademisi, agar menambah variabel independennya (indeks-indeks lainnya) karena bukan tidak mungkin variabel-varibel tersebut berpengaruh terhadap IHSG pada Bursa Efek Indonesia.

\section{Daftar Pustaka}

Achsani, N.A. (200). "Mencemati Kejatuhan Indeks Dow Jones: Akankah Indeks BEJ Ikut Terseret". FDIB Scientific E-Zine, Berline.

Anoraga, Panji dan Pakarti, Piji. 2001. Pengantar Pasar Modal, Rineka Cipta. Semarang 
Fikirman, Aries. 2006. Volatilitas Harga Saham, Indeks Harga Saham Dan Corporate Action. Jurusan Akuntansi Politeknik Pos Indonesia. Bandung.

Gouzdili, Ellya Vii. 2006. Pengaruh Pergerakan Inflasi dan Kurs Terhadap Indeks Harga Saham Gabungan Di Bursa Efek Jakarta. Skripsi Sarjana Pada Fakultas Ekonomi Universitas Andalas. Padang.

Halim, Abdul. 2005. Analisis Investasi. Salemba Empat .Jakarta

Jogiyanto, H.M.2000. Teori Portofolio dan Analisis Investasi. Edisi 2. BPFE. Yogyakarta.

Mansur, Moh.2005. Pengaruh Indeks Bursa Global Terhadap Indeks Harga Saham Gabungan (IHSG) Pada Bursa Efek Jakarta (BEJ) Periode Tahun 2000-2002. Sosiohumaniora, Vol 7. No.3.

Mulditania, Debby. 2009. Analisi Pengaruh Kinerja Keuangan Terhadap Return Saham Pada Perusahaan yang Terdaftar di Jakarta Islamic Index. Skripsi Sarjana Sarjana Pada Fakultas Ekonomi Universitas Andalas. Padang.

Pratomo, Eko Priyo dan Ubaidillah Nugraha. 2002. Analisis Perataan Penghasilan (income Smoothing): faktor-faktor yang mempengaruhinya dan pengaruhnya terhadap Kinerja Saham. Jurnal Riset Akuntansi Indonesia. Vol 3 (1) hal 17-34.

Purna, Ibnu. 2009. Stabilitas Sektor Keuangan Indonesia. Sekretariat Negara Republik Indonesia.

Santoso, Singgih. 2002. Latihan SPSS Statistik Parametrik. PT.Elex Media Komputindo: Jakarta.

\section{Komputindo: Jakarta.}

Suharli, Michell. 2005. Studi Empiris Terhadap Dua Faktor yang Mempengaruhi Return Saham Pada Industri Food \& Beverages di Bursa Efek Jakarta. Jurnal Akuntansi dan Keuangan, Vol.7, No.2.

Sugiyono. 2004. Metode Penelitian Bisnis. Alfabeta: Bandung.

Utama, Chandra. 2008. Pengaruh Pasar Saham Dunia Terhadap Pasar Saham Indonesia. The Second National Conference UKWMS. Surabaya.

www.bapepam.co.id

www.idx.co.id

www.vibiznews.com

www.duniabursa.com

www.detikfinance.com 
